\title{
Distribution and growth of Scomber japonicus and S. australasicus larvae in the southern East China Sea in response to oceanographic conditions
}

\author{
Chiyuki Sassa*, Youichi Tsukamoto
}

Seikai National Fisheries Research Institute, Fisheries Research Agency, 1551-8 Taira-machi, Nagasaki 851-2213, Japan

\begin{abstract}
Chub mackerel Scomber japonicus and spotted mackerel S. australasicus are important fishery resources in the countries adjacent to the East China Sea (ECS). During February to March in 2004 and 2005, based on species identification using PCR-restriction fragment length polymorphism (PCR-RFLP) analysis of mtDNA, we examined the larval distribution, transport and growth of both species in the southern ECS, where extremely high abundances of Scomber spp. larvae are found. Distribution of $S$. australasicus was in a more southern area than was $S$. japonicus, with a higher and narrower range of habitat temperature $\left(20\right.$ to $23^{\circ} \mathrm{C}$ versus 15 to $\left.22^{\circ} \mathrm{C}\right)$, although there was some spatial overlap. In 2004, when an intrusion of the warm Kuroshio Branch Current north of Taiwan was evident, $S$. australasicus were transported northeastward, while they dispersed eastward along the Kuroshio front in 2005 when the intrusion was weak. Although S. japonicus showed a similar pattern of transport and dispersal to $S$. australasicus, it was more gradual, corresponding with the weaker flow in the northern part of the study area. The daily specific growth rates of $S$. japonicus and $S$. australasicus were 6.2 to $8.2 \%$ and 7.7 to $9.3 \%$ of body length per day, respectively, and growth was significantly higher in 2004 than in 2005 for both species, with both habitat temperature and food availability being higher in 2004. Our study provides fundamental information on the spawning and recruitment of these 2 mackerel species on which to base predictive models, which are essential for protecting these shared stocks that migrate across the boundaries within the ECS.
\end{abstract}

KEY WORDS: Between-year difference $\cdot$ Food availability $\cdot$ Habitat temperature $\cdot$ Larval distribution Larval growth $\cdot$ PCR-RFLP analysis $\cdot$ Scomber australasicus $\cdot$ Scomber japonicus

\section{INTRODUCTION}

Understanding the recruitment dynamics of exploitable fish is a central issue in fisheries science. The early life stage is the most important stage for determining annual recruitment of fishes supporting various major commercial fisheries, and many studies have focused on ecological aspects of the larval stage, such as distribution, growth and survival (Chambers \& Trippel 1997, Fuiman \& Werner 2002). However, marine fish exhibit high species diversity, and not all larval-stage fishes, including various commercially important species, can readily be morphologically identified to the species level (e.g. Okiyama 1988, Moser 1996). Analysis of mtDNA has been used to identify fish species at all life stages (e.g. Graves et al. 1990, Chow et al. 2003, Karaiskou et al. 2005, Neira \& Keane 2008), and this method can help to examine the ecology of larval-stage fishes for which species identification cannot be readily distinguished based solely on morphological characteristics.

The chub mackerel Scomber japonicus and spotted mackerel $S$. australasicus occur widely in temperate and subtropical waters of the Indo-Pacific Ocean, and display antitropical distributions (Collette \& Nauen 1983, Scoles et al. 1998, Collette 1999). In the East China Sea (ECS), which is one of the largest marginal seas of the western Pacific Ocean, both species occur abundantly and are commercially fished, mainly with purse seines, by the countries adjacent to the ECS. These 2 species form a shared stock that migrates 
across the boundaries of adjacent Exclusive Economic Zones (EEZs) of 2 or more coastal countries (FAO 2006). The catches of $S$. japonicus and $S$. australasicus by Japanese and Korean fisheries during 2000-2008 ranged between 190000 and 307000 and between 37000 and $91000 \mathrm{t}$, respectively for the two species, in the ECS and the adjacent sea areas (Fisheries Agency \& Fisheries Research Agency of Japan 2010). Based on their gonadal development, these 2 species spawn in the ECS during February to June (Yukami et al. 2009).

Information on the processes associated with survival during the vulnerable larval stage of Scomber japonicus and $S$. australasicus in the ECS is important for understanding mechanisms of year-to-year variation in recruitment. Survival during the larval stage, i.e. during the first weeks of planktonic life, is considered critical for recruitment in the congeneric Atlantic mackerel $S$. scombrus in the northwestern Atlantic Ocean (Robert et al. 2007, Castonguay et al. 2008). In the northeastern Atlantic Ocean off the coast of Europe where considerable information has been accumulated on the egg and larval biology of $S$. scombrus, an individual-based model was developed for the prediction of year-to-year variations in transport, growth and survival of the early life stages (Bartsch \& Coombs 2004, Bartsch et al. 2004). However, information on the recruitment processes of $S$. japonicus and $S$. australasicus is limited, and little is known on the distribution and growth of the larvae in the ECS. The Fisheries Research Agency of Japan began large scale larval sampling survey from the southern to northern ECS in
2001, and extremely high abundances of Scomber spp. larvae were found in the shelf break region of the southern ECS south of $28^{\circ} \mathrm{N}$ during February to March (our Fig. 1, Sassa et al. 2006). This suggests that their primary spawning ground is formed there. However, few characteristics are available to distinguish between $S$. japonicus and S. australasicus larvae based on their morphology and pigmentation patterns (Watanabe 1970). Although Ozawa (1984) suggested that $S$. australasicus possesses distinctive melanophores on the surface of the hindbrain throughout the postlarval stage, which are not seen in $S$. japonicus, it remains to be verified how valid this feature is as a diagnostic characteristic (C. Sassa unpubl. data). Recently, a species identification method for $S$. japonicus and $S$. australasicus has been established based on PCR-restriction fragment length polymorphism (PCRRFLP) analysis of mtDNA (Sezaki et al. 2001).

In this study, we examined the distribution and abundance of Scomber japonicus and S. australasicus larvae in the southern ECS during February to March in 2004 and 2005 based on PCR-RFLP analysis of mtDNA (Sezaki et al. 2001). The distribution patterns are discussed in relation to the physical oceanography to infer the larval transport as well as between-species and between-year differences in distribution. We also examined the larval growth and the between-year differences of the 2 mackerels based on otolith increments, since early growth is one of the most important factors determining recruitment success of fishes (Takasuka et al. 2003, Takahashi \& Watanabe 2004, Robert et al.
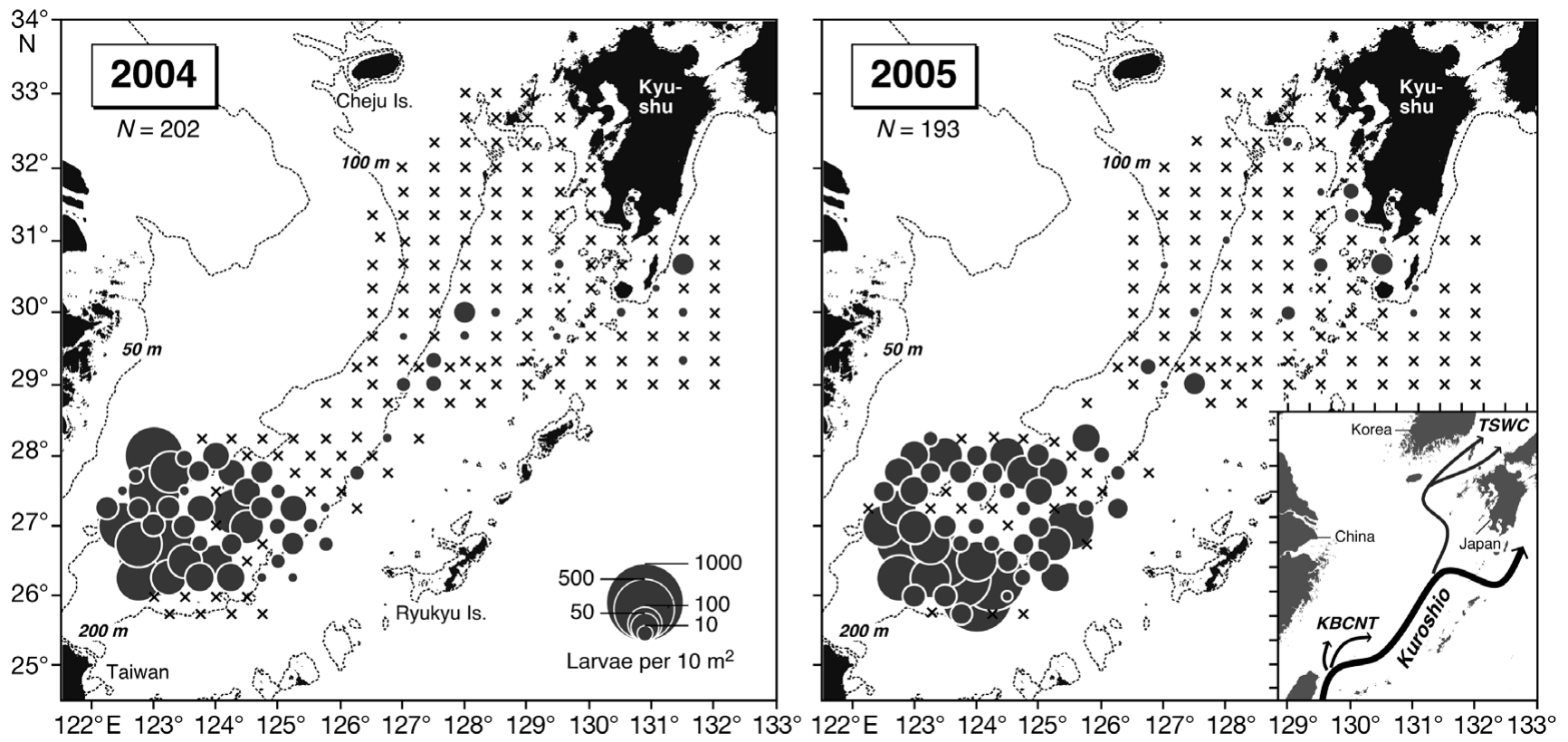

Fig. 1. Scomber japonicus and S. australasicus. Horizontal distributions of mackerel larvae in the East China Sea from February to March in 2004 and 2005. Circles represent the abundance as a continuous range of values. Crosses indicate no catch. N: total number of sampling stations; KBCNT: Kuroshio Branch Current north of Taiwan; TSWC: Tsushima Warm Current 
2007). The larval growth is discussed in response to habitat conditions, such as water temperature and food availability experienced by the larvae. Our study provides fundamental information on which to base future studies, including modeling, to allow prediction of the spawning and recruitment variability of the 2 mackerel species of these shared stocks in the ECS.

\section{MATERIALS AND METHODS}

Study area. The southern ECS between 25 and $28^{\circ} \mathrm{N}$ is an extremely dynamic oceanic region, as indicated by the prominent frontal area between the Kuroshio Current and shelf waters and the between-year difference in water mass distribution (Tang et al. 2000, Sassa et al. 2008b). Two current systems are active in the southern ECS during winter: the Kuroshio Current and the Kuroshio Branch Current north of Taiwan (KBCNT) (Fig. 2, lower right panel; Ichikawa \& Beard-

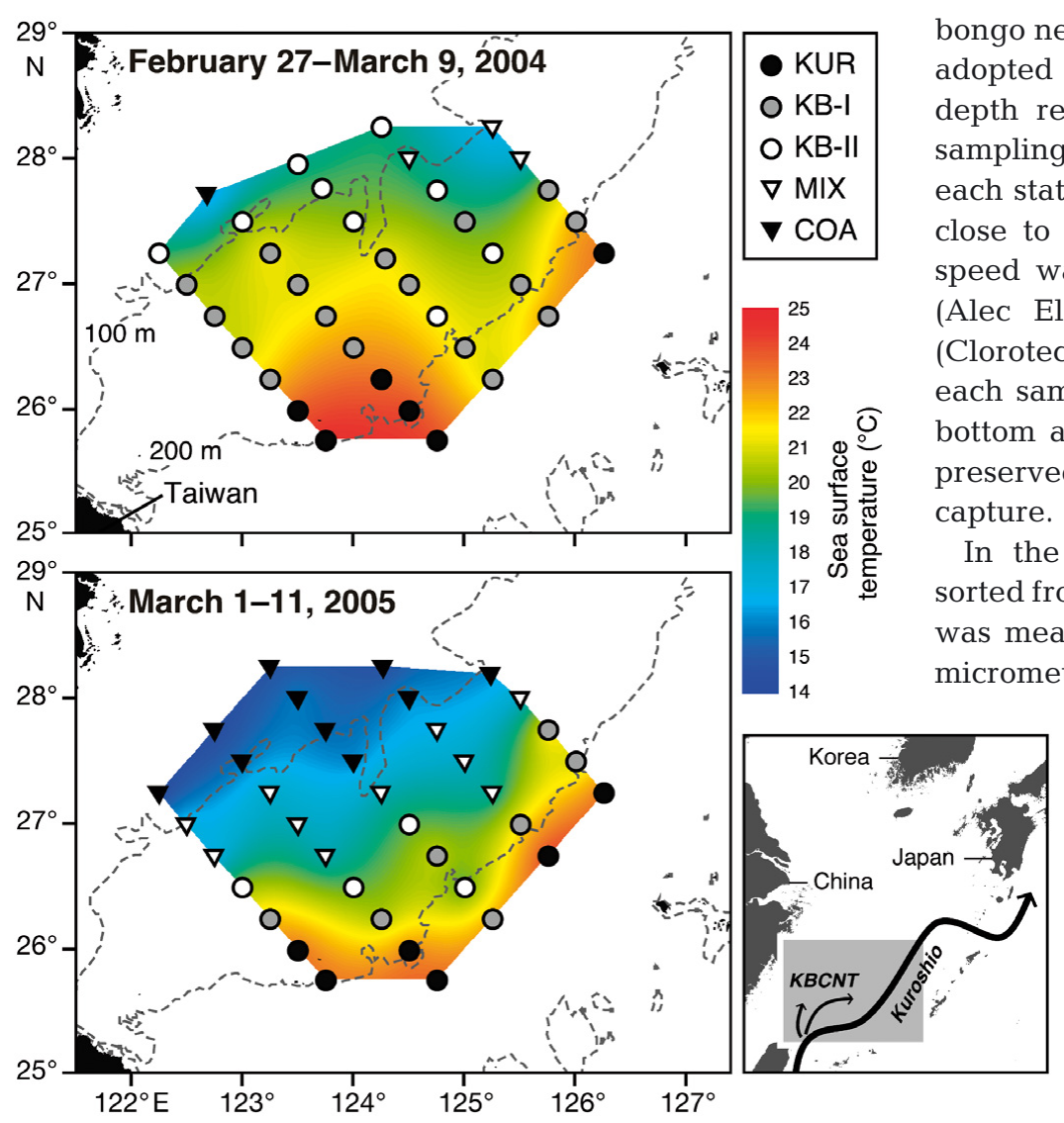

Fig. 2. Spatial distributions of the water masses detected by the cluster analysis in the shelf break region of the southern East China Sea in 2004 and 2005, with the 100 and $200 \mathrm{~m}$ isobaths marked. The $20 \mathrm{~m}$ depth water temperature and salinity were used in this analysis. The contours indicate SST $\left({ }^{\circ} \mathrm{C}\right)$. KUR: Kuroshio waters; KB-I: Kuroshio branch current waters-I; KB-II: Kuroshio branch current waters-II; COA: coastal waters; MIX: mixed waters. KBCNT: Kuroshio Branch Current north of Taiwan sley 2002, Lie \& Cho 2002). The main stream of the Kuroshio Current flows along the $200 \mathrm{~m}$ isobath at the shelf break. A branch of the Kuroshio Current intrudes onto the shelf $(<200 \mathrm{~m}$ depth) northeast of Taiwan between $\sim 122$ and $\sim 125^{\circ} \mathrm{E}$, i.e. the KBCNT (Ichikawa $\&$ Beardsley 2002). The KBCNT flows first northward and then northeastward at a relatively slow speed. The intrusion of the Kuroshio waters is related to the northeast monsoon; thus, the KBCNT is expected to be prevalent in winter (Gong et al. 1997, Ichikawa \& Beardsley 2002). These 2 currents can significantly affect transport processes of larval carangid fishes (Kasai et al. 2008, Sassa et al. 2008b).

Sample collection. Larvae were collected along 5 transects in the shelf break region of the southern ECS between $25^{\circ} 45^{\prime} \mathrm{N}$ and $28^{\circ} 15^{\prime} \mathrm{N}$ in 2004 and 2005 (Fig. 2). From 27 February to 9 March 2004 and between 1 and 11 March 2005, samples were collected at 36 and 37 stations, respectively, from the RV 'YokoMaru' (Seikai National Fisheries Research Institute, Fisheries Research Agency; 499 t) (Fig. 2). A paired bongo net ( $60 \mathrm{~cm}$ mouth diameter, $0.33 \mathrm{~mm}$ mesh) was adopted for larval sampling, with a flowmeter and depth recorder attached to the net for quantitative sampling. A double-oblique tow was conducted at (1) shallow stations. The towing Alec Electronics) with a submersible fluorometer Clorotec, ACL220-PDK, Alec Electronics) was used at each sampling station to $200 \mathrm{~m}$ depth or close to the at shallower stations. Plankton samples were ture.

laboratory, all Scomber spp. larvae were the samples and counted. Body length (BL) as measured to the nearest $0.1 \mathrm{~mm}$ with an ocular of a stereomicroscope. Notochord length (NL) was measured for preflexion larvae and standard length (SL) for flexion and postflexion larvae (Moser 1996). No correction was made for larval shrinkage due to net capture or preservation by the ethanol. Each larva was numbered and individually preserved in a separate vial for further analysis. In total, we collected 368 and 274 Scomber spp. larvae in 2004 and 2005, respectively, of which, 306 and 254 larvae, respectively, in good condition were used for DNA and otolith extraction.

Species identification. Total DNA from the muscle tissues of Scomber spp. larvae was extracted using the DNeasy Tissue Kit (QIAGEN). DNA fragments encoding the mitochondrial cytochrome $b$ gene were 
amplified by the PCR using the primer pair SACB-7L (5'-AGT CCC ATA CGT CGG TAC TA-3') and SACB8H (5'-CAT TCA GGC TTA ATA TGA GG-3') (Sezaki et al. 2001). The reaction mixtures were preheated at $98^{\circ} \mathrm{C}$ for $30 \mathrm{~s}$ followed by 30 cycles of amplification (at $98^{\circ} \mathrm{C}$ for $10 \mathrm{~s}$ in denaturation, $55^{\circ} \mathrm{C}$ for $30 \mathrm{~s}$ in annealing, and $72^{\circ} \mathrm{C}$ for $60 \mathrm{~s}$ in extension) with a final polymerization step at $72^{\circ} \mathrm{C}$ for $120 \mathrm{~s}$. Amplified products were purified with the GFX ${ }^{\mathrm{TM}}$ PCR DNA and Gel Band Purification Kit (Amersham Biosciences).

The full length of the cytochrome $b$ gene consisted of 1140 nucleotides irrespective of Scomber japonicus and $S$. australasicus, in which 16 species-specific variations were observed (Sezaki et al. 2001). Among the various restriction enzymes that recognize the cytochrome $b$ genes from the 2 fish species, MvaI is specific to the gene of $S$. japonicus and Mbol to that of $S$. australasicus, with both enzymes producing 2 fragments (Sezaki et al. 2001). In this study, the $10 \mu \mathrm{l}$ of amplified products were directly digested by 2 restriction enzymes (MvaI and MboI) for $1 \mathrm{~h}$. The digested samples were electrophoresed through $1.5 \%$ agarose gel (Agarose X, Nippon Gene) for $\sim 25$ min. The DNA bands were visualized and photographed after electrophoresis and staining with ethidium bromide.

In the present study, $98.9 \%$ of the larvae showed restriction fragment length polymorphism (RFLP) profiles consistent with those of Sezaki et al. (2001) (see 'Results - Species identification'). For the other 6 larvae having inconsistent RFLP profiles, the nucleotide sequences of the cytochrome $b$ were determined. Then, the species identifications were carried out by comparing the sequences between the larvae and morphologically well-identified adults (DDBJ/EMBL/ GenBank under accession numbers AB032515AB032520).

Hydrographic analysis. To clarify the position of the Kuroshio axis along the shelf break, currents were measured with an acoustic Doppler current profiler (ADCP) and were routinely monitored at 10, 25 and $50 \mathrm{~m}$ depths throughout the cruise. However, it is not possible to accurately assess the position and flow strength of the KBCNT, since the flow direction and velocity on the shelf region of the ECS fluctuates with the diurnal and semidiurnal tidal flows (Katoh et al. 2000). Thus, we defined the KBCNT based on water mass distributions and sea surface temperature (SST) fields.

A cluster analysis using water temperature and salinity at $20 \mathrm{~m}$ depth was conducted to distinguish the water properties at each sampling station. Since (1) the water column is mixed vertically in winter due to the strong northeast monsoon and the mixed layer depth is usually deeper than $30 \mathrm{~m}$ (Ichikawa \& Beardsley 2002,
Sassa et al. 2006), and (2) Scomber spp. larvae are concentrated in the upper $30 \mathrm{~m}$ layer with peak densities at $\sim 20 \mathrm{~m}$ depth in the southern ECS (C. Sassa unpubl. data), the temperature and salinity at $20 \mathrm{~m}$ directly represent the water properties in the epipelagic layer where the larvae occur. The standardised Euclidean distance was used to evaluate the dissimilarity between water properties of each sampling station. Clustering by the farthest neighbour strategy was used to construct dissimilarity matrices for data of the total 73 sampling stations (Wilks 1995, Sassa et al. 2008b). Cluster analysis was performed with the PRIMER v.6 software package (Clarke \& Gorley 2006). We used similarity profile permutation tests (SIMPROF, PRIMER v.6) to identify significant clusters of locations at the $95 \%$ significance level.

Analysis of larval distribution. The description of the geographic distribution of larvae was based on their abundance (number of larvae per $10 \mathrm{~m}^{2}$ sea surface). If the catch was too large to identify all larvae using mtDNA (only 4 stations), the larvae randomly picked out from the sample at the station were analysed and the total abundance of Scomber spp. was multiplied by the ratio of $S$. japonicus to $S$. australasicus. To examine the larval transport processes, horizontal distributions were analyzed using the following 2 body size classes: $<5 \mathrm{~mm}$ and $\geq 5 \mathrm{~mm}$ BL (hereafter referred to as 'small larvae' and 'large larvae', respectively). Notochord flexion begins to occur between 5 and $6 \mathrm{~mm}$ BL (Ozawa 1984); thus, the small larvae were at the preflexion stage, while the large larvae included flexion and postflexion stages.

Spatial overlap between Scomber japonicus and $S$. australasicus larvae was measured in each size class during 2004 and 2005 using Schoener's index (Schoener 1970) which, in this case, compared the relative proportions of the square root-transformed abundance of each species. This index ranges from $0 \%$ (no overlap) to $100 \%$ (complete overlap).

Since species-specific temperature optima during the early life stages are key to understanding multispecies population dynamics (Takasuka et al. 2008), quotient analysis (Ibaibarriaga et al. 2007, Neira \& Keane 2008) was performed on larval abundance data across 2 surveys combined to describe characteristics of the habitat temperature of each species. We used temperatures at $20 \mathrm{~m}$ depth of each station. For this analysis, square root-transformed abundance of the larvae within $1^{\circ} \mathrm{C}$ temperature classes was expressed as a percentage of total abundance, divided by the percentage frequency of stations under each temperature. Quotients > 1 indicate positive habitat selection, i.e. range of optimum temperature.

Chlorophyll a concentration and copepod nauplii density. The chlorophyll a ( $\mathrm{chl}$ a) fluorescence mea- 
sured by the Clorotec was calibrated based on standard procedures using extracted chl a from $250 \mathrm{ml}$ water samples at $20 \mathrm{~m}$ depth (Sassa \& Konishi 2006). The chl a concentration $\left(\mathrm{mg} \mathrm{m}^{-2}\right)$ was integrated for the 0 to $50 \mathrm{~m}$ water column.

Copepod nauplii are an important prey item for Scomber spp. larvae in the study area (Sassa et al. 2008a). Data on nauplii density were taken from Okazaki et al. (2008). The nauplii were collected from $1 \mathrm{l}$ of surface water and concentrated using a plankton net with $0.05 \mathrm{~mm}$ mesh and fixed in $5 \%$ buffered formalin seawater. Since there was no significant difference in the nauplii density between the sea surface and $20 \mathrm{~m}$ depth (C. Sassa unpubl. data), we used data at the sea surface as a proxy for the food available to the larvae.

The weighted mean values of temperature (WMT), chl a concentration (WMC) and copepod nauplii density (WMN) of Scomber japonicus and S. australasicus habitat for each of the 2 body size class were calculated using the following equations for each year:

$$
\begin{aligned}
& \mathrm{WMT}=\sum_{i=1}^{n}\left(s_{i} \times t_{i}\right) / \sum_{i=1}^{n} s_{i} \\
& \mathrm{WMC}=\sum_{i=1}^{n}\left(s_{i} \times c_{i}\right) / \sum_{i=1}^{n} s_{i} \\
& \mathrm{WMN}=\sum_{i=1}^{n}\left(s_{i} \times n_{i}\right) / \sum_{i=1}^{n} s_{i}
\end{aligned}
$$

where $S_{i}$ is the abundance of $S$. japonicus or $S$. australasicus larvae in the $i$ th sampling station (no. larvae $10 \mathrm{~m}^{-2}$ ), and $t_{i}, c_{i}$ and $n_{i}$ are the water temperature at $20 \mathrm{~m}$ depth, the chl a concentration and the copepod nauplii density at the $i$ th sampling station, respectively. Before the analysis, the larval abundance was square root-transformed to reduce the bias caused by sampling stations with extremely large catches.

Otolith analysis and growth rates. Sagittal otoliths were extracted from all Scomber spp. larvae identified to the species level, and increments were counted under a microscope to determine growth. The first increment was observed at approximately $5 \mu \mathrm{m}$ from the otolith core in both larvae. Since the otolith radius of newly hatched larvae of $S$. australasicus was approximately $5 \mu \mathrm{m}$ in a rearing experiment (M. Saito, Japan NUS Co. Ltd. pers. comm.), we defined the first increment as the hatch check, and the total increment number on the outside of the hatch check as age. We postulated that the increments were deposited daily, as determined in studies for S. japonicus and S. scombrus (Mendiola \& Álvarez 2008, M. Takahashi unpubl. data).

Instantaneous growth rate $(G)$ and relative growth rate $(K)$ were estimated as follows (Yamashita \& Bailey 1989, Mendiola et al. 2009):

$$
L_{t}=L_{0} \cdot \mathrm{e}^{G \cdot t}
$$

and

$$
K=\mathrm{e}^{G}-1
$$

where $L_{0}$ is the initial body length $(\mathrm{mm})$ and $L_{t}$ is the body length at time $t$ (d). The daily specific growth rate was defined as $K \times 100 \%$ (Mendiola et al. 2009). To test the suitability of the exponential model, the body length-at-age data were also fitted by linear regression.

The differences in the instantaneous growth rates $(G)$ by years and by species were evaluated using analysis of covariance (ANCOVA), which was performed for linearised exponential models.

\section{RESULTS}

\section{Water mass distributions and current features}

Based on a cluster analysis, 5 water masses were recognized (SIMPROF, p < 0.05) (Fig. 2). Based on their temperature and salinity (T-S) properties and distributions, they were respectively named the Kuroshio waters, Kuroshio branch current waters-I and -II, coastal waters, and mixed waters (hereafter KUR, KB-I, KB-II, COA, and MIX, respectively) (Figs. 2 \& 3a). Temperature gradually decreased from the highest values in the KUR $\left(22.9\right.$ to $\left.24.4^{\circ} \mathrm{C}\right)$ to the lowest in the COA (13.8 to $15.8^{\circ} \mathrm{C}$ ) (Fig. 3a). Salinity in the KUR, KB-I, and KB-II was high (34.5 to 34.8) with no significant difference (KruskalWallis, $\mathrm{p}>0.05)$, while salinity in both the MIX and COA was lower and broader in range (34.1 to 34.8 and 33.4 to 34.6 , respectively) compared with the above 3 subareas (Mann-Whitney $U$-test, p $<0.05$ ) (Fig. 3a).

Between $\sim 26$ and $\sim 29^{\circ} \mathrm{N}$, the Kuroshio front was observed along the $200 \mathrm{~m}$ isobath at the shelf break based on the ADCP observations during our cruises. This corresponds with the boundary between the 2 water masses of the KUR and KB-I and the SST fields ( 21 to $23^{\circ} \mathrm{C}$ isotherms) in both years (Fig. 2).

Water mass distribution was significantly different between 2004 and 2005 (Fig. 2). An intrusion of the Kuroshio branch current north of Taiwan (KBCNT) was much more evident in 2004 than in 2005, since the distribution of the KB-I and KB-II in 2004 extended more northward to $\sim 28^{\circ} \mathrm{N}$ (Fig. 2). In 2005, on the other hand, the KBCNT was weak based on the water mass distribution and the SST fields. Instead, it was notable that the cold COA extended southward to $\sim 27^{\circ} \mathrm{N}$ (Fig. 2). SST was significantly higher in 2004 than in $2005\left(20.8 \pm 2.0\right.$ versus $18.8 \pm 3.0^{\circ} \mathrm{C}$, mean $\left.\pm \mathrm{SD}\right)$ (Mann-Whitney $U$-test, $\mathrm{p}<0.05$ ). 

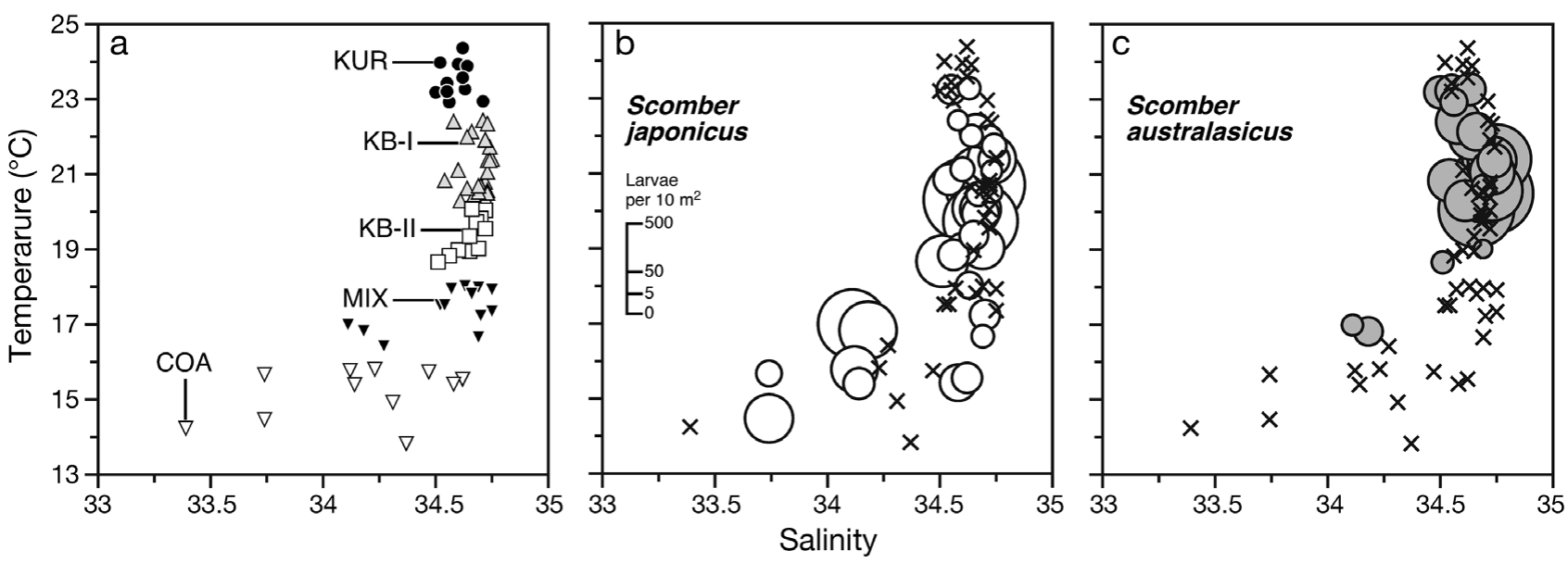

Fig. 3. (a) Temperature-salinity (T-S) diagram for each of the 73 sampling stations at $20 \mathrm{~m}$ depth. Each water mass resulting from the cluster analysis is shown by symbols. $(\mathrm{b}, \mathrm{c})$ Numerical abundance of Scomber japonicus and S. australasicus larvae in relation to the temperature and salinity of their habitats. Circles represent the abundance as a continuous range of values $>0$. Crosses indicate no catch. KUR: Kuroshio waters; KB-I: Kuroshio branch current waters-I; KB-II: Kuroshio branch current waters-II; COA: coastal waters; MIX: mixed waters

\section{Chl a concentration and copepod nauplii density}

In 2004, high concentrations of $\mathrm{chl} a\left(>40 \mathrm{mg} \mathrm{m}^{-2}\right)$ were observed over a wide area in the northwest edge and central part of the study area (Fig. 4), corresponding with the KBCNT area (Fig. 2). In 2005, on the other hand, the high chl a concentrations were restricted in a narrower area of the northeast edge of the study area (Fig. 4). In both years, the chl a concentrations were low in the KUR, with a mean value of $22 \mathrm{mg} \mathrm{m}^{-2}$ (Fig. 4). Mean $( \pm \mathrm{SD}) \mathrm{chl}$ $a$ concentrations in 2004 and 2005 were $37.8 \pm 14.4$ and $30.3 \pm 9.8 \mathrm{mg} \mathrm{m}^{-2}$, respectively, and chl a was significantly higher in 2004 (Mann-Whitney $U$-test, p < 0.05).

The nauplii density showed positive correlations with chl a concentration (Pearson's correlation coefficient: $r=0.433, \mathrm{n}=73, \mathrm{p}<0.05)$. In 2004, high densities of nauplii ( $>15$ ind. $\mathrm{l}^{-1}$ ) were observed mainly in the KBCNT area (Figs. $2 \& 4$ ). In 2005, the nauplii densities were lower than those in 2004, although the maximum density of 41 ind. $\mathrm{l}^{-1}$ was observed at the northernmost station (Fig. 4). In both years, the nauplii densities were low in the KUR, with mean density of 5 ind. $\mathrm{l}^{-1}$ (Fig. 4).

\section{Species identification}

A total of 544 Scomber spp. larvae ranging from 2.6 to $11.7 \mathrm{~mm}$ BL were identified to species level based on the PCR-RFLP analysis. Only 6 larvae showed inconsistent RFLP profiles with those described by Sezaki et al. (2001), and all of them were assigned to S. australasicus based on the nucleotide sequence analysis. Ten
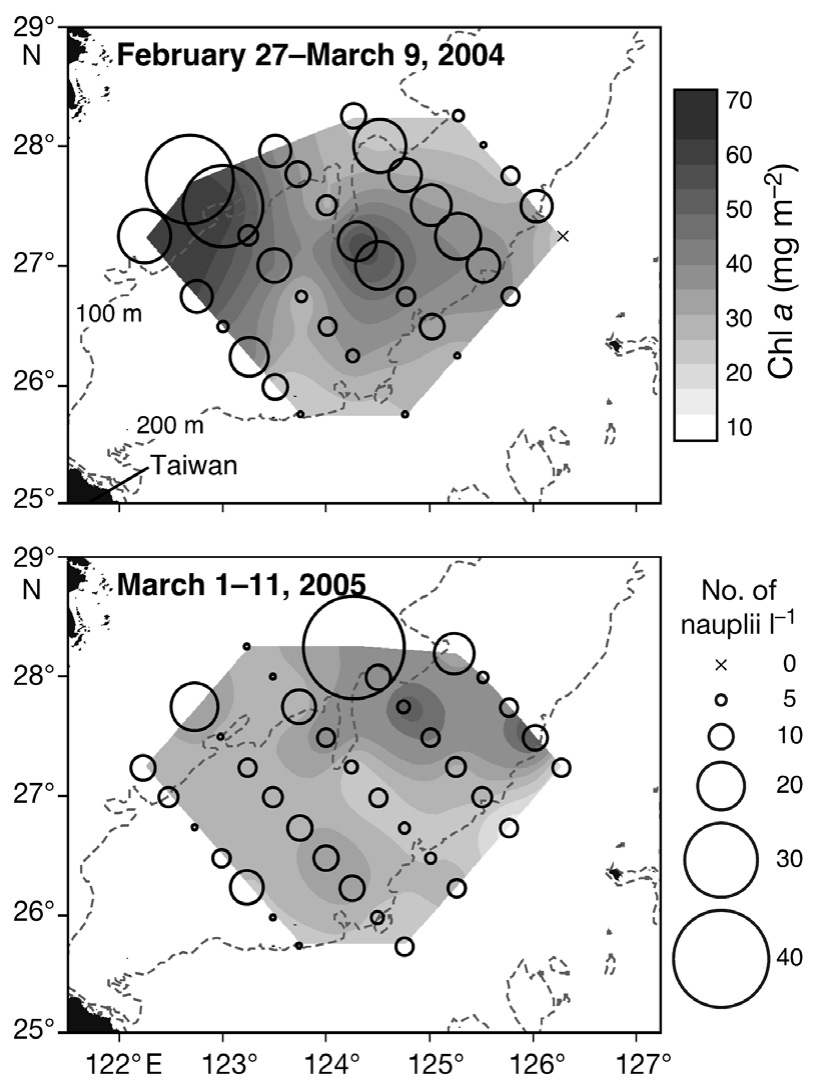

Fig. 4. Horizontal distributions of the chl a concentration (mg $\mathrm{m}^{-3}$ ) in the upper $50 \mathrm{~m}$ of the water column and copepod nauplii density (ind. $\mathrm{l}^{-1}$ ) at the sea surface in the southern East China Sea in 2004 and 2005. Contours indicate the chl a concentration. Circles represent the nauplii density as a continuous range of values $>0$. Cross indicates no catch. The 100 and $200 \mathrm{~m}$ isobaths are shown with dashed lines 
larvae were unidentifiable since the DNA extracted was not sufficient to analyse, possibly due to problems related to sample preservation. In the present study, $S$. japonicus and $S$. australasicus accounted for 57.6 and $42.4 \%$ of the total larvae identified, respectively.

\section{Larval abundance and body length}

Mean abundances of Scomber japonicus larvae in 2004 and 2005 were comparable, with values of 27.4 and 32.5 larvae $10 \mathrm{~m}^{-2}$, respectively (Mann-Whitney $U$-test, p > 0.05) (Table 1). Mean abundance of $S$. australasicus larvae in 2004 was 36.3 larvae $10 \mathrm{~m}^{-2}$, which was approximately twice that of 2005, although no significant difference was detected (Mann-Whitney U-test, p > 0.05). In both years, there were no significant differences in abundances between species (Mann-Whitney $U$ test, $\mathrm{p}>0.05$ ) (Table 1).

Larval Scomber japonicus and S. australasicus larvae were significantly larger in 2004 (5.7 and $5.4 \mathrm{~mm} \mathrm{BL}$, respectively) than in 2005 (4.9 and 5.0 mm BL, respectively) (Mann-Whitney $U$-test, p < 0.05) (Fig. 5).

\section{Larval distribution and transport}

Small larvae of Scomber japonicus ( $<5 \mathrm{~mm} \mathrm{BL}$ ) were collected abundantly to the west of $124^{\circ} \mathrm{E}$ in 2004 , with mean abundance of 70.1 larvae $10 \mathrm{~m}^{-2}$ at positive stations (Fig. 6a). Distribution of the large larvae ( $\geq 5 \mathrm{~mm} \mathrm{BL}$ ) tended to extend northeastward

Table 1. Scomber japonicus and S. australasicus. Percentage of positive tows and mean \pm SE abundance (ind. $10 \mathrm{~m}^{-2}$ ) of the larvae in the shelf break region of the southern East China Sea in 2004 and 2005. n: total number of fish collected

\begin{tabular}{|lcccc|}
\hline Sampling period & Species & $\mathrm{n}$ & $\begin{array}{c}\text { Positive } \\
\text { tows (\%) }\end{array}$ & $\begin{array}{c}\text { Abundance } \\
\text { (ind. 10 } \mathrm{m}^{-2} \text { ) }\end{array}$ \\
\hline 27 Feb- & S. japonicus & 147 & 50.0 & $27.4 \pm 12.0$ \\
9 Mar 2004 & S. australasicus & 149 & 30.6 & $36.3 \pm 14.2$ \\
1-11 Mar 2005 & S. japonicus & 170 & 48.6 & $32.5 \pm 12.0$ \\
& S. australasicus & 84 & 29.7 & $14.7 \pm 8.1$ \\
\hline
\end{tabular}

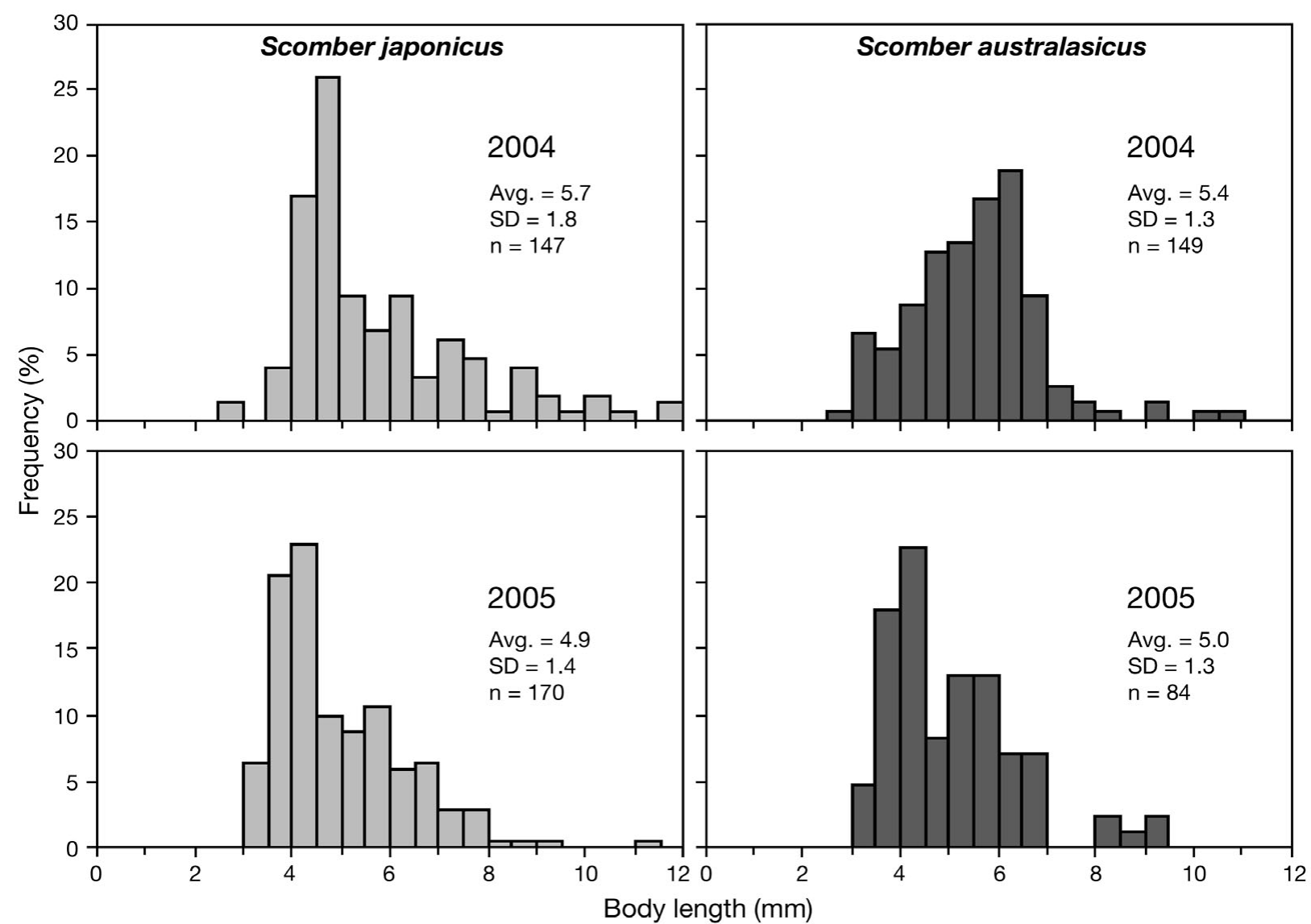

Fig. 5. Scomber japonicus and $S$. australasicus. Length frequency distributions of larvae collected by a bongo net in the southern East China Sea in 2004 and 2005. n: total number of fish collected 


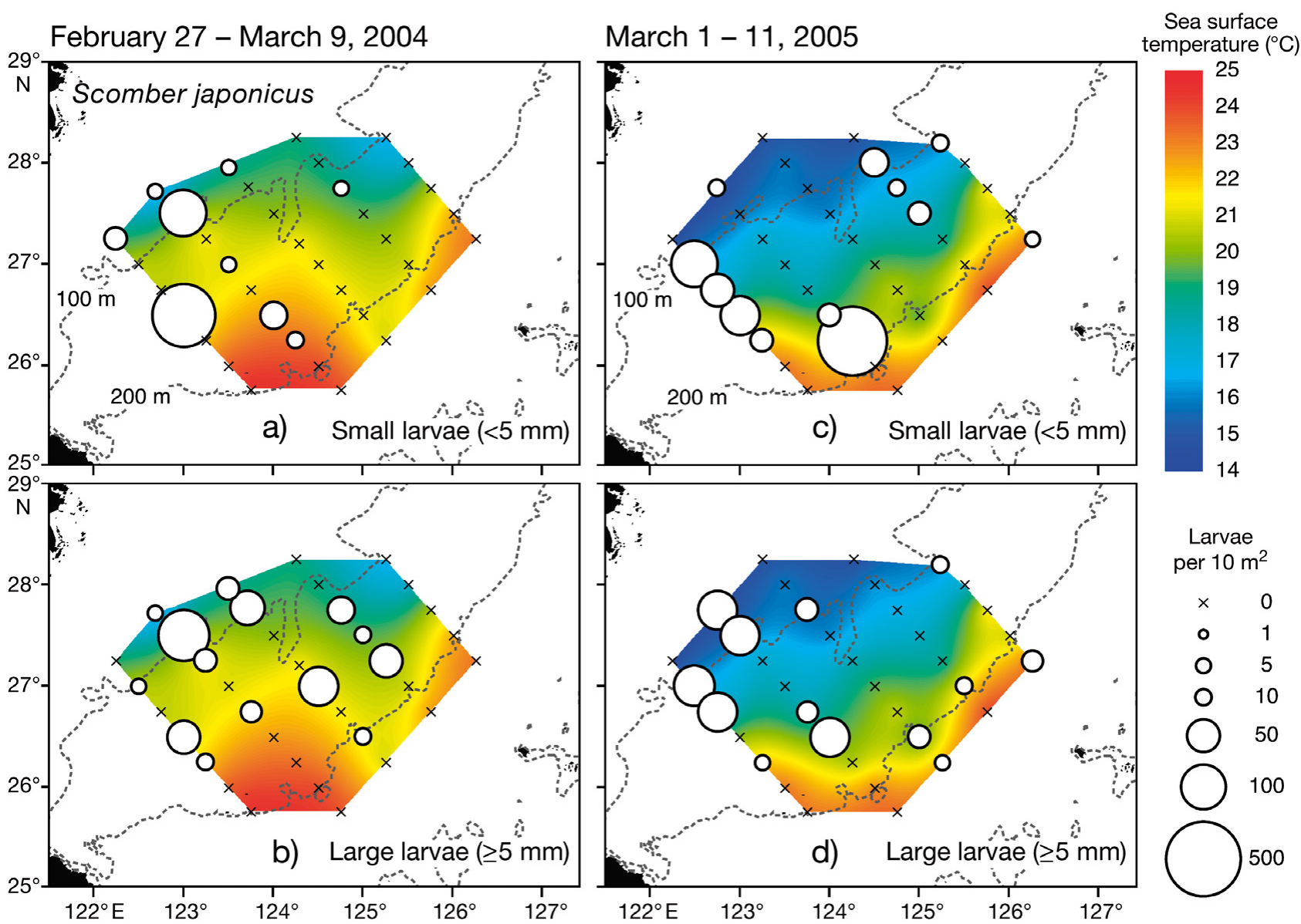

Fig. 6. Scomber japonicus. Horizontal distributions of the 2 size classes of the larvae and SST $\left({ }^{\circ} \mathrm{C}\right)$ in the southern East China Sea in 2004 and 2005. Circles represent the abundance as a continuous range of values $>0$. Crosses indicate no catch. The 100 and $200 \mathrm{~m}$ isobaths are shown with dashed lines. $\mathrm{n}$ : total number of larvae collected

to $125^{\circ} 30^{\prime} \mathrm{E}$ (Fig. 6b), corresponding with the intrusion of the KBCNT (Fig. 2). In 2005, the small larvae of $S$. japonicus occurred abundantly in the westernmost transect and the Kuroshio Current frontal area at $\sim 124^{\circ} \mathrm{E}$ (Fig. 6c). In addition, they were collected in the northeastern area between $124^{\circ} 30^{\prime} \mathrm{E}$ and $125^{\circ} 30^{\prime} \mathrm{E}$, but with a relatively low abundance (Fig. 6c). In 2005, distribution of the large larvae shifted slightly northeastward in the area west of $123^{\circ} 30^{\prime} \mathrm{E}$ (Fig. 6d), although this pattern was not so clear compared with that in the previous year. The large larvae also occurred along the Kuroshio front in the area east of $124^{\circ} \mathrm{E}$, with a relatively low abundance (Fig. 6d).

The small larvae of Scomber australasicus were concentrated to the west of $124^{\circ} \mathrm{E}$ between 26 and $27^{\circ} \mathrm{N}$ in 2004 , with mean abundance of 76.5 larvae $10 \mathrm{~m}^{-2}$ at positive stations (Fig. 7a). As larvae grew, their center of distribution shifted northward and northeastward (Fig. 7b), corresponding closely with the direction of the KBCNT (Fig. 2). In 2005, the abundance and dis- tribution pattern of the small larvae of $S$. australasicus was similar to that in the previous year (Fig. 7c), while that of the large larvae was considerably different from that in the previous year, i.e. they showed a dispersed pattern along the Kuroshio front (Fig. 7d). The change in larval transport conditions corresponded with the between-year difference in the pattern of the currents (Fig. 2).

\section{Difference in distribution and habitat temperature between species}

In both years, the percentage of positive tows of Scomber japonicus larvae showed higher values than that of $S$. australasicus (48.6 to 50.0 versus 29.7 to $30.6 \%$ ) (Table 1), and the distributional area was broader in $S$. japonicus larvae (Figs. 6 \& 7). Although there were sampling stations where both $S$. japonicus and $S$. australasicus larvae were abundantly collected, the center of distribution tended to differ between spe- 


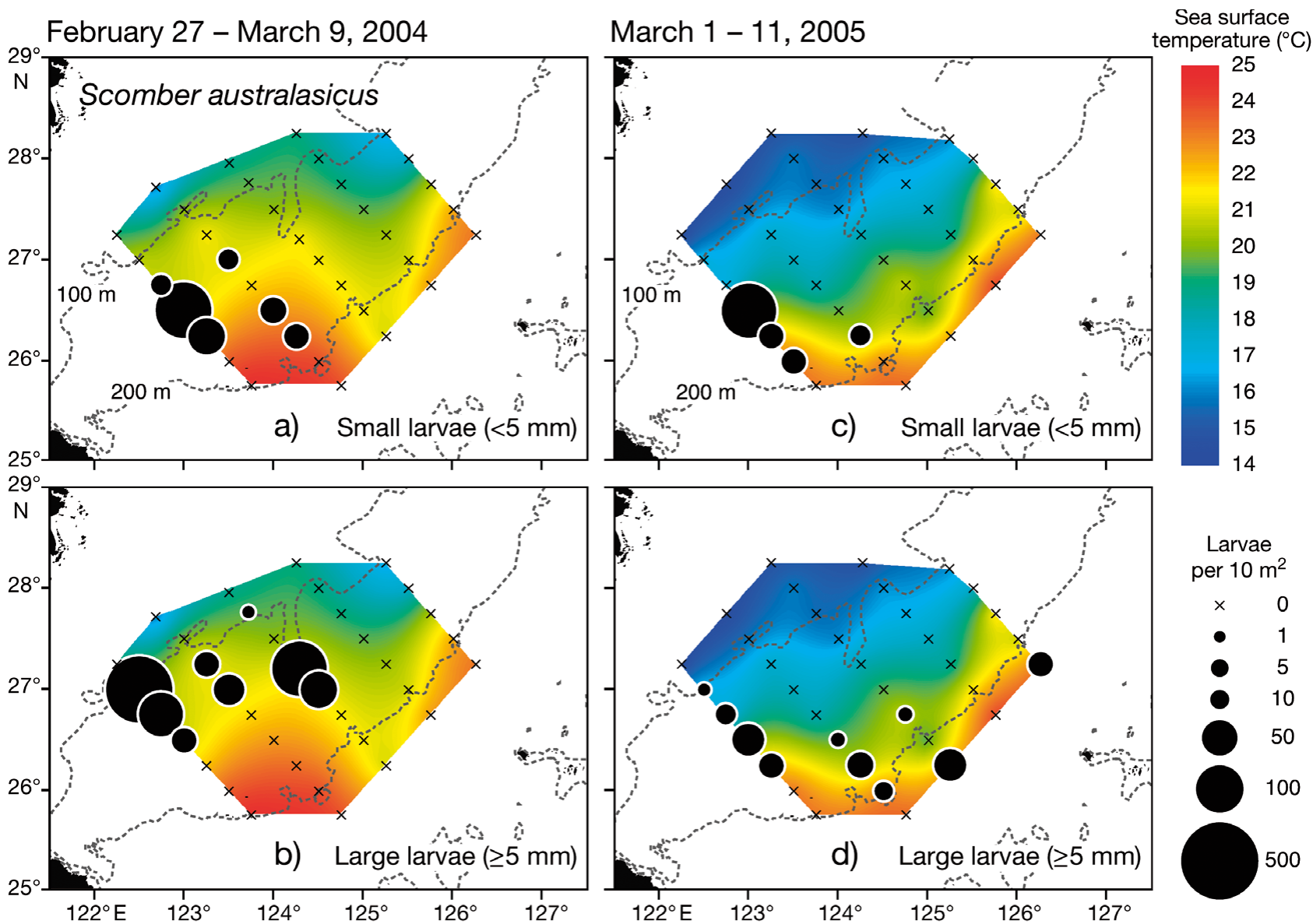

Fig. 7. Scomber australasicus. Horizontal distributions of the 2 size classes of the larvae and SST $\left({ }^{\circ} \mathrm{C}\right)$ in the southern East China Sea in 2004 and 2005. Other details as in Fig. 6

cies in both size classes (Figs. 6 \& 7). That is, the distribution center of $S$. australasicus was in a slightly more southern area than that of $S$. japonicus. In 2004, spatial overlap of these 2 species, based on Schoener's index, was relatively high at $54.9 \%$ in small larvae, but it declined to $31.4 \%$ in large larvae. The spatial overlap in 2005 was low in both small and large larvae (29.9 and $31.2 \%$, respectively).

High abundances of Scomber japonicus larvae were observed broadly in the 5 water masses (Fig. 3b), while those of $S$. australasicus larvae were restricted mainly in the KUR and KB-I (Fig. 3c). The abundance quotients of $S$. japonicus larvae across 2 surveys showed high values (>1) between 15 and $22^{\circ} \mathrm{C}$, except between 18 and $19^{\circ} \mathrm{C}$ (Fig. 8). On the other hand, the abundance quotients of $S$. australasicus larvae peaked sharply

Fig. 8. Scomber japonicus and S. australasicus. Quotient lines of abundance of the larvae with respect to the $20 \mathrm{~m}$ depth water temperature. Bars indicate percentage frequency of occurrences in each temperature class. Quotient value $>1$ (above dashed line) indicates a positive temperature selection

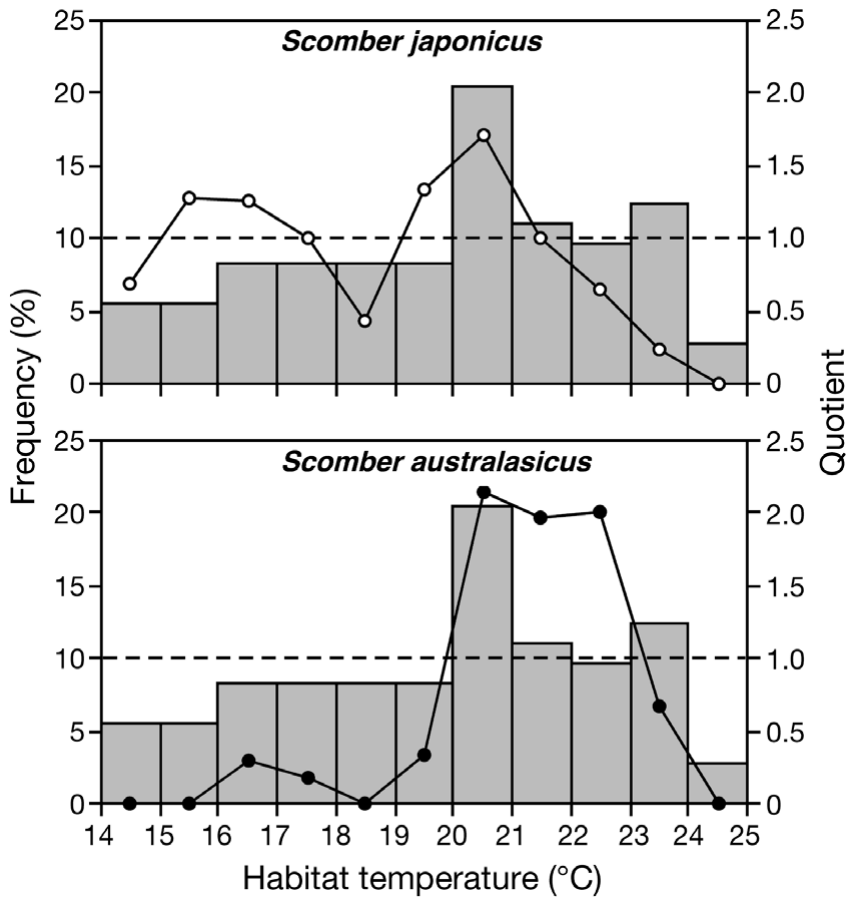


between 20 and $23^{\circ} \mathrm{C}$ (Fig. 8), showing a higher and narrower range of habitat temperature than that of $S$. japonicus, although there was overlap between 20 and $22^{\circ} \mathrm{C}$.

\section{Larval growth and its between-year variations}

The exponential model fitted the body length (BL) and age data of both species better than the linear model (Fig. 9, Table 2), except for data of Scomber japonicus in 2005 when the linear model fitted better than the exponential one $\left(\mathrm{r}^{2}=0.858\right.$ versus 0.837$)$. In both species, there were significant differences in the instantaneous growth rate $(G)$ between the 2 yr. That is, $G$ of both species in 2004 was significantly higher than values in 2005 (ANCOVA: df $=1, F=30.88$, p < 0.05 for $S$. japonicus; $\mathrm{df}=1, F=8.95, \mathrm{p}<0.05$ for $S$. australasicus) (Fig. 9, Table 2).

The daily specific growth rate $(K)$ of Scomber japonicus larvae was higher in $2004\left(8.2 \% \mathrm{BL} \mathrm{d}^{-1}\right)$ than in 2005 (6.2\% BL d ${ }^{-1}$ ) (Table 2). Similarly, $K$ of $S$. australasicus larvae was higher in $2004\left(9.3 \% \mathrm{BL} \mathrm{d}^{-1}\right)$ than in $2005\left(7.7 \% \mathrm{BL} \mathrm{d}^{-1}\right)$, although the between-year difference was smaller compared with that of $S$. japonicus (Table 2).
Table 2. Scomber japonicus and S. australasicus. Parameters of $L_{t}=L_{0} \cdot \mathrm{e}^{G \cdot t}$ growth equations of the larvae in the shelf break region of the southern East China Sea in 2004 and 2005. $L_{0}$ is the initial body length; $G$ and $K$ (in \%) are the instantaneous and daily specific growth rates for body length, respectively. $\mathrm{n}$ : total number of fish analyzed

\begin{tabular}{|lcccccc|}
\hline Species & Year & $L_{0}$ & $G$ & $K$ & $\mathrm{n}$ & $\mathrm{r}^{2}$ \\
\hline S. japonicus & 2004 & 2.516 & 0.079 & 8.2 & 147 & 0.838 \\
& 2005 & 2.947 & 0.060 & 6.2 & 170 & 0.837 \\
S. australasicus & 2004 & 2.300 & 0.089 & 9.3 & 146 & 0.799 \\
& 2005 & 2.622 & 0.074 & 7.7 & 84 & 0.859 \\
\hline
\end{tabular}

Predicted absolute growth rates of Scomber japonicus between 5 and $15 \mathrm{~d}$ were 0.28 to 0.63 and 0.23 to $0.42 \mathrm{~mm} \mathrm{~d}^{-1}$ in 2004 and 2005, respectively, and those of $S$. australasicus were 0.31 to 0.74 and 0.27 to 0.57 $\mathrm{mm} \mathrm{d}^{-1}$ in 2004 and 2005, respectively (Table 3). The predicted absolute growth rates of both species of larvae increased with age (Table 3 ).

\section{Between-year variations in habitat conditions}

The WMT of Scomber japonicus habitat was $\sim 2$ to $3^{\circ} \mathrm{C}$ higher in 2004 than in 2005 in both size classes,

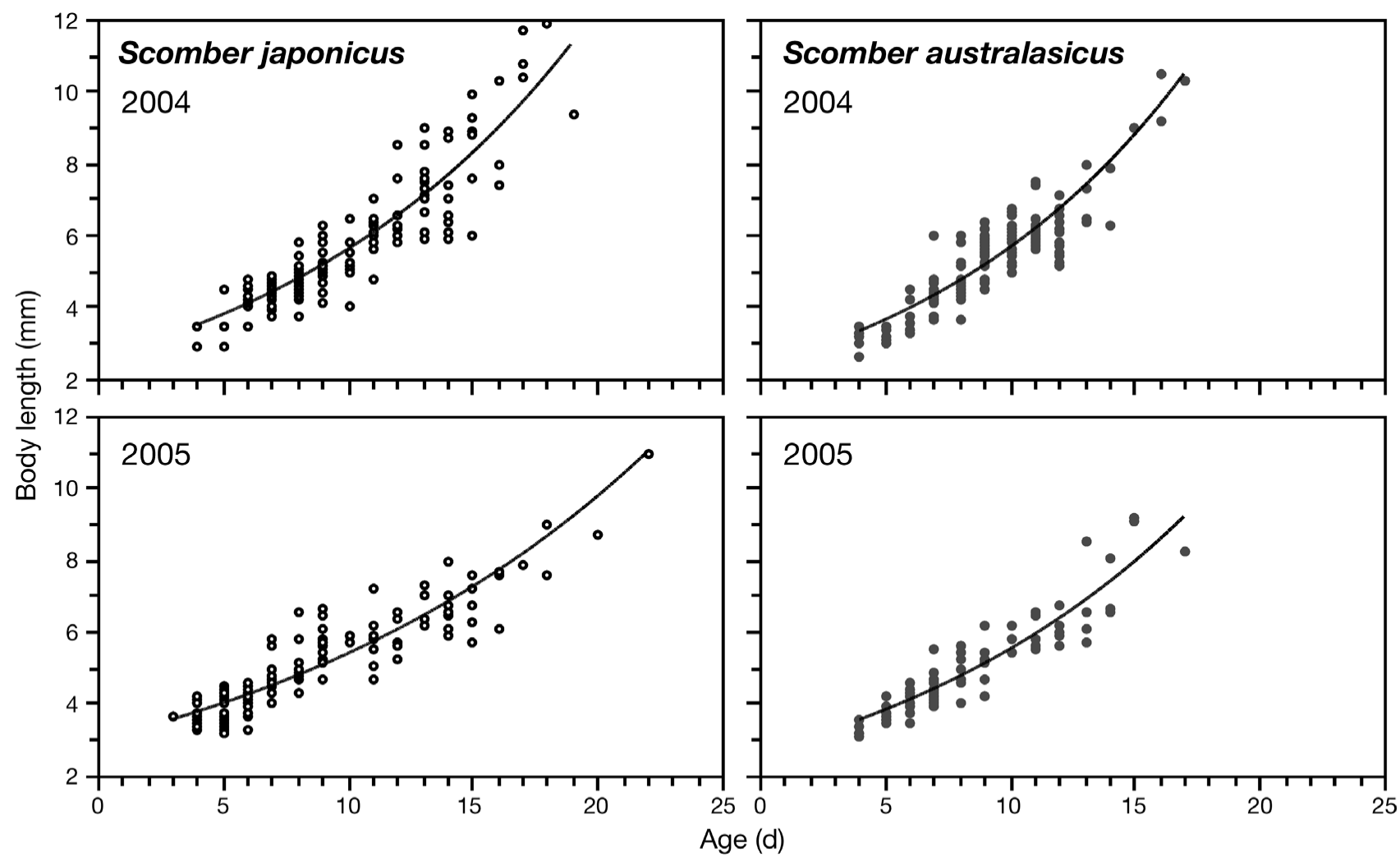

Fig. 9. Scomber japonicus and S. australasicus. Growth of larvae in the southern East China Sea in 2004 and 2005 based on daily increment counts of sagittal otoliths. Regression equations and growth coefficients are shown in Table 2 
Table 3. Scomber japonicus and S. australasicus. Predicted absolute growth rates $\left(\mathrm{mm} \mathrm{d}^{-1}\right)$ of the larvae at various ages from hatching in 2004 and 2005

\begin{tabular}{|lcccc|}
\hline \multirow{2}{*}{$\begin{array}{l}\text { Age } \\
\text { (d) }\end{array}$} & \multicolumn{2}{c}{ S. japonicus } & \multicolumn{2}{c|}{ S. australasicus } \\
\hline 5 & 2004 & 2005 & 2004 & 2005 \\
\hline 10 & 0.28 & 0.23 & 0.31 & 0.27 \\
15 & 0.42 & 0.31 & 0.48 & 0.39 \\
& 0.63 & 0.42 & 0.74 & 0.57 \\
\hline
\end{tabular}

while there was no remarkable between-year difference in the WMT of $S$. australasicus habitat, i.e. only 0.1 to $0.5^{\circ} \mathrm{C}$ higher in 2004 (Table 4).

In 2004, the occurrence of Scomber japonicus and $S$. australasicus larvae (Figs. 6 \& 7) closely corresponded with the area of high chl a concentration (>40 $\mathrm{mg} \mathrm{m}^{-3}$ ) (Fig. 4). In 2005, on the other hand, they occurred in the area where the chl a concentration was low (15 to $30 \mathrm{mg} \mathrm{m}^{-3}$ ). The weighted mean chl a concentration (WMC) of both $S$. japonicus and $S$. australasicus habitat was 1.5 times higher in 2004 than in 2005 (Table 4).

The WMN of Scomber japonicus habitat was much higher in 2004 than in 2005 in both size classes (15.5 to 16.5 versus 9.4 to 9.7 ind. $\mathrm{l}^{-1}$ ) (Table 4 ). The WMN of $S$. australasicus habitat was slightly higher in 2004 than in 2005 (9.3 to 10.5 versus 8.1 ind. ${ }^{-1}$ ) (Table 4).

\section{DISCUSSION}

\section{Limitations of the sampling and analysis}

In this study, dense distributions of Scomber japonicus and $S$. australasicus larvae were observed in the southern ECS in both 2004 and 2005; however, there are 3 potential limitations in our sampling and analysis. Firstly, the abundance of larvae of both species in the southern ECS should be considered as an underestimate in this study since a large number of larvae of both species occurred at the westernmost stations. In the west of our study area, there is usually a northeastward flow with a maximum speed sometimes reaching $\sim 0.6$ to 0.8 knots, although

Table 4. Scomber japonicus and $S$. australasicus. Weighted mean temperature $\left(\mathrm{WMT},{ }^{\circ} \mathrm{C}\right)$, chl a concentration $\left(\mathrm{WMC}, \mathrm{mg} \mathrm{m}^{-3}\right.$ ) and copepod nauplii density (WMN, ind. $\mathrm{l}^{-1}$ ) associated with larvae of each size class during 2004 and 2005

\begin{tabular}{|llcccccc|}
\hline \multirow{2}{*}{ Species } & \multirow{2}{*}{ Size class (mm) } & \multicolumn{2}{c}{ WMT } & \multicolumn{2}{c}{ WMC } & \multicolumn{2}{c|}{ WMN } \\
& & 2004 & 2005 & 2004 & 2005 & 2004 & 2005 \\
\hline \multirow{2}{*}{ S. japonicus } & Small larvae $(<5)$ & 20.4 & 18.7 & 50.0 & 32.6 & 15.5 & 9.4 \\
& Large larvae $(\geq 5)$ & 20.3 & 17.7 & 46.2 & 28.8 & 16.5 & 9.7 \\
S. australasicus & Small larvae $(<5)$ & 21.5 & 21.0 & 43.7 & 28.2 & 9.3 & 8.1 \\
& Large larvae $(\geq 5)$ & 20.9 & 20.8 & 57.1 & 27.0 & 10.5 & 8.1 \\
\hline
\end{tabular}

inter-seasonal differences are known; i.e. the main route changes off northeastern Taiwan and a low velocity of $<0.1$ to 0.2 knots is observed outside of the flow (Tang et al. 2000). This indicates that their distribution extends to the west of our study area, i.e. in the coastal and offshore waters around Taiwan. Although the occurrence of Scomber spp. larvae in the inshore and offshore waters of northeast Taiwan has been reported, differences in distribution of each species were not differentiated based on biochemical techniques (Chiu 1999).

Secondly, the present study might not clarify the northern border of the distribution of Scomber japonicus. The lower limit of the habitat temperature of S. japonicus larvae was $\sim 15^{\circ} \mathrm{C}$. Based on monthly mean SST fields in the ECS during the study periods (Japan Meteorological Agency, available at www.jma. go.jp/jma/; accessed $20 \mathrm{Mar} 2010$ ), the $15^{\circ} \mathrm{C}$ isotherm extended to $\sim 29^{\circ} \mathrm{N}$ in 2004 ; thus, the distribution of $S$. japonicus larvae would have been underestimated. In 2005 , on the other hand, our survey covered the $15^{\circ} \mathrm{C}$ isotherm in the study area.

Finally, in the present study, species identification was based on the mtDNA, that is maternal inheritance; thus, our method could not detect hybrid individuals if they occur. Although the Schoener's spatial overlap index between Scomber japonicus and S. australasicus showed relatively low values, both species were collected abundantly at the few sampling stations where hybrid individuals might potentially be produced. Although occurrence of morphologically intermediate adult individuals between the 2 mackerels has been reported, Kijima et al. (1986), using isozyme markers, could not find genetic evidence of hybridization among them. Species identification using nuclear DNA analysis is needed to clarify the occurrence of hybrid larvae in the field.

\section{Species identification}

The reliability of PCR-RFLP analysis depends on the magnitude of intraspecific variation, which requires a large number of wild samples (Chow \& Inoue 1993, Chow et al. 2003). In the present study, $98.9 \%$ of

larvae were identified to species based on the PCR-RFLP analysis. Only 6 larvae had inconsistent RFLP profiles and all were identified as Scomber australasicus by the nucleotide sequence analysis. This indicated that there were intraspecific variations in the cytochrome $b$ gene sequences in $S$. australasicus from those reported by Sezaki et al. (2001), but the frequency of occurrence was low $(<3 \%)$. 


\section{Spawning ground}

High abundances of the small larvae of Scomber japonicus and $S$. australasicus $(<5 \mathrm{~mm} \mathrm{BL})$ were observed in the shelf break region of the southern ECS south of $27^{\circ} \mathrm{N}$ during February to March. Since larvae of this size are less than $10 \mathrm{~d}$ old after fertilization (Fig. 9), the distributional area of the small larvae would represent the approximate location of the spawning ground. Based on the analysis of seasonal gonad development of adults, both $S$. japonicus and $S$. australasicus spawn primarily during February to March off the coast of northeastern Taiwan (Ku \& Tzeng 1985a,b), which corresponds with the larval occurrence of the both species in the present study. Based on catch statistics and biometric data, the potential spawning ground of both species is estimated to be in the broad area of the shelf break region of the ECS between 26 and $31^{\circ} \mathrm{N}$ during February to March (Yukami et al. 2009). From our study, the estimated spawning ground was determined to be much more specific.

The distribution center of larvae tended to differ between species, and Scomber australasicus occurred in a slightly more southern area than did $S$. japonicus, although there were also some spatial overlaps. These larval distribution patterns suggest that spawning areas for the 2 species are separate within the main location of the spawning ground.

\section{Larval distribution in response to oceanographic conditions}

The difference in distribution patterns between species corresponded closely with the optimal habitat temperature of each species. Although there was overlap between 20 and $22^{\circ} \mathrm{C}$, the habitat temperature of Scomber japonicus larvae showed a lower and broader range than that of $S$. australasicus $\left(15\right.$ to $22^{\circ} \mathrm{C}$ versus 20 to $23^{\circ} \mathrm{C}$ ). Mature $S$. australasicus tends to occur in higher water temperature areas than does $S$. japonicus in the ECS ( 17 to $25^{\circ} \mathrm{C}$ versus 15 to $22^{\circ} \mathrm{C} \mathrm{SST}$ ) (Yukami et al. 2009), which corresponds with the difference of larval habitat temperature. Water temperature where S. japonicus larvae occur are at 15 to $22^{\circ} \mathrm{C}$ in the Pacific coast off central Japan (Watanabe 1970), 14 to $21.9^{\circ} \mathrm{C}$ in the eastern North Pacific (Kramer 1960) and 16 to $22^{\circ} \mathrm{C}$ in the Gulf of California (Esqueda-Escarcega 1995), which corresponds closely with our observations. No information is available on the habitat temperature of $S$. australasicus larvae in the North Pacific and its adjacent waters. In southeastern Australia, they occurred at 17.5 to $20.5^{\circ} \mathrm{C}$ (Neira \& Keane 2008), which is significantly lower than the habitat temperature in our study area, i.e. the optimal temperature for this species appears to be different among populations. Since between-year change of water mass distribution is observed in the southern ECS during winter (Tang et al. 2000, Sassa et al. 2008b), interannual variation would also occur in the area of optimal habitat temperature for $S$. japonicus and $S$. australasicus larvae. This might cause year-to-year variations in the extent of spawning and nursery grounds of each species.

During the early life history, Scomber spp. are considered to be passively transported by currents until entering the juvenile stage of $20 \mathrm{~mm} \mathrm{SL}, \sim 3$ to $4 \mathrm{wk}$ after fertilization in laboratory rearing conditions, when they begin to swim actively and form schools (Watanabe 1970, Hunter \& Kimbrell 1980, Masuda et al. 2002). There are 2 routes of larval transport from the spawning ground in the southern ECS (our Fig. 2, lower right; Kasai et al. 2008, Sassa et al. 2008b). One route is entrained by the $\mathrm{KBCNT}$; i.e. first, the larvae are transported northward and then northeastward at a slow speed of $\sim 0.2$ to 0.5 knots. Another is a rapid northeastward transport by the Kuroshio Current, which sometimes reaches 1.5 to 3 knots. Based on a particle-tracking model, in 17 to $30 \mathrm{~d}$ a high percentage of larvae in the southern ECS transported by the former process would recruit into the shelf region of the ECS, and those transported by the Kuroshio Current would reach the Pacific Ocean off the coast of southern Japan (Kasai et al. 2008). In 2004, when an intrusion of the warm KBCNT was evident, $S$. australasicus larvae were transported northeastward as they grew, while they dispersed eastward along the Kuroshio front in 2005 when the intrusion of the KBCNT was weak. Although $S$. japonicus larvae showed a similar pattern, it was much more gradual than that of $S$. australasicus, corresponding with the weaker flow in the northern part of the study area (Tang et al. 2000, Kasai et al. 2008) where S. japonicus mainly occurred.

Since the current features in the southern ECS are highly variable and complex on both spatial and temporal scales due to the relative strength of the Kuroshio intrusions, tidal current and mesoscale frontal disturbances (Gong et al. 1997, Tang et al. 2000, Lie \& Cho 2002, Sassa et al. 2008b), the larval transport process of the 2 mackerel species would fluctuate over relatively short periods in the southern ECS. Although our study was based on a 'snapshot' observation, the results suggest that a small difference in the larval distribution and the oceanographic conditions would lead to a remarkable difference in the transport route and the end point of transportation. Based on a particle-tracking model, Kasai et al. (2008) reported year-to-year variations in transport processes of larval carangids originating from the spawning ground in the southern 
ECS, supporting the above view. Furthermore, as discussed below, the difference in physical oceanographic conditions would also be related to the difference in larval habitat conditions, resulting in betweenyear variations in the larval growth.

\section{Larval growth in response to habitat conditions}

This study is the first to report the larval growth of Scomber japonicus and $S$. australasicus in the ECS. The exponential model gave the best fits to the age-length relationship of the 2 mackerels, which agree with the growth of $S$. japonicus reported for laboratory rearing experiments (Hunter \& Kimbrell 1980, Mendiola et al. 2009). The daily specific growth rate of $S$. japonicus in our study ranged from $6.2 \% \mathrm{BL} \mathrm{d}^{-1}$ at the habitat temperature of 17.7 to $18.7^{\circ} \mathrm{C}$ to $8.2 \% \mathrm{BL}$ $\mathrm{d}^{-1}$ at 20.3 to $20.4^{\circ} \mathrm{C}$ (Tables $2 \& 4$ ). These values are within the range of the growth rates reported in the rearing conditions, i.e. from $2.9 \% \mathrm{BL} \mathrm{d}^{-1}$ at $16^{\circ} \mathrm{C}$ to $8.8 \% \mathrm{BL} \mathrm{d}^{-1}$ at $22^{\circ} \mathrm{C}$ (Mendiola et al. 2009). There is no information on the growth of $S$. australasicus larvae under laboratory rearing conditions to allow comparison with our results.

The growth rates of larvae of both species were significantly higher in 2004 than in 2005, and the between-year difference was larger in Scomber japonicus (Table 2). Interannual differences are also found in the growth of the congener Atlantic mackerel larvae in the northwest Atlantic Ocean (Robert et al. 2007). Our results would relate to the between-year difference in habitat temperature and food availability for larvae, since larval growth is a function of these 2 factors (Yamashita et al. 2001, Fuiman \& Werner 2002, Takasuka \& Aoki 2006). The WMT of $S$. japonicus habitat was 2 to $3^{\circ} \mathrm{C}$ higher in 2004 than in 2005, corresponding with the higher growth rate in 2004. For S. australasicus, on the other hand, there was only a slight difference $\left(0.1\right.$ to $0.5^{\circ} \mathrm{C}$ higher in 2004) in the habitat temperature between the $2 \mathrm{yr}$, which would be related to the stenothermal nature of this species (Fig. 8).

Scomber spp. larvae $<6 \mathrm{~mm}$ BL feed mainly on copepod nauplii, and with growth, calanoid copepodites, especially Paracalanus spp., and appendicularians become more important as prey (Sassa et al. 2008a). $S$. japonicus and $S$. australasicus larvae were distributed in an area with higher nauplii density in 2004 than the density in the area in which they were found in 2005 (Table 4). There were areas of high nauplii density in 2005, but neither species was abundant in these. In addition, in 2004 larvae of both species occurred in the area of higher chl a concentration compared with that in 2005 (Table 4). Okazaki et al. (2008) indicate that the egg production rate of Paracalanus spp. was signifi- cantly higher in 2004 than in 2005 (25.2 versus 19.4 eggs female $\mathrm{d}^{-1}$ ) in our study area due to higher temperature and chl a concentration. In addition, appendicularian abundance might also have been higher in 2004, since it shows positive relations with temperature and chl a concentration (López-Urrutia et al. 2005, Xu \& Zhang 2010). These observations suggest that the food availability for both $S$. japonicus and S. australasicus in 2004 was better for larval growth compared with that in 2005, although this assumption is based on the limited spatial and temporal data examined.

The difference in food availability between the $2 \mathrm{yr}$ could relate to the difference in the physical oceanographic conditions, i.e. an intrusion of the warm KBCNT in 2004 was much more evident compared with 2005 (Fig. 2). A permanent upwelling is found at the shelf break northeast of Taiwan, centered at $\sim 25^{\circ} 15^{\prime} \mathrm{N}$ to $\sim 25^{\circ} 45^{\prime} \mathrm{N}$ and $\sim 121^{\circ} 45^{\prime} \mathrm{E}$ to $\sim 122^{\circ} 45^{\prime} \mathrm{E}$ (Gong et al. 1997, Hsu et al. 2000, Wong et al. 2000). Although the intensity of upwelling is weak during winter when the northeastern monsoon is dominant (Ichikawa \& Beardsley 2002), the upwelled waters would be a major source of nutrients that support primary production in southern ECS (Gong et al. 1997, Wong et al. 2000). The intrusion of the KBCNT is considered to bring the nutrient-enriched upwelled subsurface waters northeastward from the upwelling area to our study area (Gong et al. 1997). Additionally, in the KBCNT area where a frontal structure between the Kuroshio and coastal waters is formed, the mixed layer depth becomes relatively shallow and water column stability is kept high even in winter due to the development of a pycnocline (Nakata et al. 2007). The shallow mixed layer depth and high water temperature is also thought to enhance phytoplankton production (Nakata et al. 2007). Thus, the higher chl a concentration in 2004 would be related to the stronger KBCNT intrusion, resulting in better conditions for prey production; although, further study is needed for a better understanding of the prey production mechanism.

Since fast-growing larvae are considered to have a higher probability of surviving than slow-growing larvae (Takasuka et al. 2003, Takahashi \& Watanabe 2004, Robert et al. 2007), the rate of growth would affect year-to-year variations in survival and recruitment. In the ECS and the western Japan Sea, recruitment success, expressed as recruit per spawner (RPS), of age-0 Scomber japonicus and $S$. australasicus in 2004 is calculated to be 2.6 and 2.3 times higher, respectively, than in 2005, based on analysis of population dynamics (Fisheries Agency and Fisheries Research Agency of Japan 2010). The higher recruitment success in 2004 corresponded with the higher larval growth rate in 2004. In S. scombrus, during years of higher temperature and food availability, higher larval 
growth rates are hypothesized to allow more larvae to survive to the juvenile stage, resulting in higher yearclass strength (Ringuette et al. 2002, Castonguay et al. 2008). A similar relationship might explain variations in recruitment of the 2 mackerel species in the ECS. In future, the relationships among the larval habitat conditions, larval growth and the year-to-year variations in their recruitment need to be clarified for $S$. japonicus and $S$. australasicus in the ECS to allow predictive models for their stocks to be developed.

Acknowledgements. We are grateful to the captains, officers and crews of the RV 'Yoko-Maru' for their assistance in the field sampling. Drs. Y. Okazaki of Tohoku National Fisheries Research Institute and K. Nishiuchi of the Seikai National Fisheries Research Institute provided raw data on copepod nauplii. We thank Drs. Y. Konishi and M. Takahashi of Seikai National Fisheries Research Institute for discussions during the course of this study. We also thank Ms. M. Saito and Mr. T. Kitamura of Japan NUS Co. Ltd. for helping with the larval identification and otolith reading. This work was supported by the Japan Fisheries Agency.

\section{LITERATURE CITED}

Bartsch J, Coombs SH (2004) An individual-based model of the early life history of mackerel (Scomber scombrus) in the eastern North Atlantic, simulating transport, growth and mortality. Fish Oceanogr 13:365-379

Bartsch J, Reid D, Coombs SH (2004) Simulation of mackerel (Scomber scombrus) recruitment with an individual-based model and comparison with field data. Fish Oceanogr 13: 380-391

Castonguay M, Plourde S, Robert D, Runge JA, Fortier L (2008) Copepod production drives recruitment in a marine fish. Can J Fish Aquat Sci 65:1528-1531

Chambers RC, Trippel EA (eds) (1997) Early life history and recruitment in fish populations. Fish and Fisheries Series 21, Chapman \& Hall, London

Chiu TS (1999) Marine fish larvae and juveniles around Taiwan. National Museum of Marine Biology and Aquarium, Kaohsiung (in Chinese)

Chow S, Inoue S (1993) Intra- and interspecific restriction fragment length polymorphism in mitochondrial genes of Thunnus tuna species. Bull Nat Res Inst Far Seas Fish 30: 207-225

Chow S, Nohara K, Tanabe T, Itoh $\mathrm{T}$ and others (2003) Genetic and morphological identification of larval and small juvenile tunas (Pisces: Scombridae) caught by a midwater trawl in the western Pacific. Bull Fish Res Agency 8: $1-14$

Clarke KR, Gorley RN (2006) PRIMER v6: user manual/tutorial. PRIMER-E, Plymouth

Collette BB (1999) Mackerels, molecules, and morphology. In: Séret B, Sire JY (eds) Proc 5th Indo-Pac Fish Conf Nouméa 1997. Soc Fr Ichtyol, Paris, p 149-164

Collette BB, Nauen CE (1983) FAO species catalogue, Vol 2. Scombrids of the world. An annotated and illustrated catalogue of tunas, mackerels, bonitos and related species known to date. FAO Fish Synop 125, Rome

Esqueda-Escarcega GM (1995) Spatial and temporal distribution of Scomber japonicus larvae in the Sea of Cortez (1984-1988). Sci Mar 59:391-397
FAO (2006) FAO yearbook: fishery statistics - capture production, Vol 98/1, 2004. FAO Fish Ser 72, Rome

Fisheries Agency and Fisheries Research Agency of Japan (2010) Marine fisheries stock assessment and evaluation for Japanese waters (fiscal year 2009/2010). Fisheries Agency and Fisheries Research Agency of Japan, Tokyo and Yokohama (in Japanese)

Fuiman LA, Werner RG (eds) (2002) Fishery science. The unique contributions of early life stages. Blackwell Publishing, Oxford

Gong GC, Shiah FK, Liu KK, Chuang WS, Chang J (1997) Effect of Kuroshio intrusion on the chlorophyll distribution in the southern East China Sea north of Taiwan during spring, 1993. Cont Shelf Res 17:79-94

Graves JE, Curtis MJ, Oeth PA, Waples RS (1990) Biochemical genetics of southern California basses of the genus Paralabrax: specific identification of fresh and ethanolpreserved individual eggs and early larvae. Fish Bull 88: $59-66$

> Hsu MK, Liu AK, Liu C (2000) A study of internal waves in the China Seas and Yellow Sea using SAR. Cont Shelf Res 20: 389-410

Hunter JR, Kimbrell CA (1980) Early life history of Pacific mackerel, Scomber japonicus. Fish Bull 78:89-101

> Ibaibarriaga L, Irigoien X, Santos M, Motos L and others (2007) Egg and larval distributions of seven fish species in north-east Atlantic waters. Fish Oceanogr 16:284-293

Ichikawa H, Beardsley RC (2002) The current system in the Yellow and East China seas. J Oceanogr 58:77-92

Karaiskou N, Triantafyllidis A, Margaroni M, Karatzas D, Triantaphyllidis C (2005) A double DNA approach for identifying Macrorhamphosus scolopax (Pisces, Centriscidae). ICES J Mar Sci 62:1683-1690

Kasai A, Komatsu K, Sassa C, Konishi Y (2008) Transport and survival processes of eggs and larvae of jack mackerel Trachurus japonicus in the East China Sea. Fish Sci 74: $8-18$

Katoh O, Morinaga K, Nakagawa N (2000) Current distributions in the southern East China Sea in summer. J Geophys Res 105:8565-8573

Kijima A, Taniguchi N, Ochiai A (1986) Genetic divergence and morphological difference between the spotted and common mackerel. Jpn J Ichthyol 33:151-161

Kramer D (1960) Development of eggs and larvae of Pacific mackerel and distribution and abundance of larvae 1952-56. Fish Bull 60:393-438

Ku JF, Tzeng WN (1985a) Age and growth of common mackerel (Scomber japonicus) in the waters of northeastern Taiwan, with particular reference to the subpopulation discrimination. J Fish Soc Taiwan 12:1-11

Ku JF, Tzeng WN (1985b) Age and growth of spotted mackerel, Scomber australasicus (Cuvier), in the shelf waters of northeastern and southwestern Taiwan. J Fish Soc Taiwan 12:12-26

- Lie HJ, Cho CH (2002) Recent advances in understanding the circulation and hydrography of the East China Sea. Fish Oceanogr 11:318-328

López-Urrutia A, Harris RP, Acuña JL, Båmstedt U and others (2005) A comparison of appendicularian seasonal cycles in four distinct European coastal environments. In: Gorsky G, Youngbluth MJ, Deibel D (eds) Response of marine ecosystems to global change: ecological impact of appendicularians. GB Scientific Publisher, Paris, p 255-276

Masuda R, Shoji J, Aoyama M, Tanaka M (2002) Chub mackerel larvae fed with fish larvae can swim faster than those fed with rotifers and Artemia nauplii. Fish Sci 68:320-324 
Mendiola D, Álvarez P (2008) Validation of daily increments in the otolith microstructure of Northeast Atlantic mackerel fish larvae. Fish Res 89:300-304

Mendiola D, Yamashita Y, Matsuyama M, Masuda R, Okamoto K, Alvarez P, Tanaka M (2009) Estimation of the daily food intake and gross growth efficiency of chub mackerel (Scomber japonicus) larvae under various temperatures. Aquacult Sci 57:291-299

Moser HG (ed) (1996) The early stages of fishes in the California Current region. CalCOFI atlas no. 33, Allen Press, Lawrence, KS

Nakata H, Nishiuchi K, Okazaki Y (2007) Variations in copepod distribution in the East China Sea. Kaiyo Monthly 446: 545-549 (in Japanese)

Neira FJ, Keane JP (2008) Ichthyoplankton-based spawning dynamics of blue mackerel (Scomber australasicus) in south-eastern Australia: links to the East Australian Current. Fish Oceanogr 17:281-298

Okazaki Y, Noguchi T, Nakata H, Nishiuchi K (2008) Distribution and abundance of copepod nauplii in southern part of the East China Sea: implications for prey availability to jack mackerel Trachurus japonicus larvae. Fish Sci 74:1235-1244

Okiyama M (ed) (1988) An atlas of the early stage fishes in Japan. Tokai University Press, Tokyo (in Japanese)

Ozawa T (1984) The postlarvae of spotted mackerel Scomber australasicus Cuvier (Pisces, Scombridae). Bull Jpn Soc Sci Fish 50:1317-1321

Ringuette M, Castonguay M, Runge JA, Grégoire F (2002) Atlantic mackerel (Scomber scombrus) recruitment fluctuations in relation to copepod production and juvenile growth. Can J Fish Aquat Sci 59:646-656

Robert D, Castonguay M, Fortier L (2007) Early growth and recruitment in Atlantic mackerel Scomber scombrus: discriminating the effects of fast growth and selection for fast growth. Mar Ecol Prog Ser 337:209-219

Sassa C, Konishi Y (2006) Vertical distribution of jack mackerel Trachurus japonicus larvae in the southern part of the East China Sea. Fish Sci 72:612-619

Sassa C, Konishi Y, Mori K (2006) Distribution of jack mackerel (Trachurus japonicus) larvae and juveniles in the East China Sea, with special reference to the larval transport by the Kuroshio Current. Fish Oceanogr 15:508-518

Sassa C, Tsukamoto Y, Konishi Y (2008a) Diet composition and feeding habits of Trachurus japonicus and Scomber spp. larvae in the shelf break region of the East China Sea. Bull Mar Sci 82:137-153

Sassa C, Tsukamoto Y, Nishiuchi K, Konishi Y (2008b) Spawning ground and larval transport processes of jack mackerel Trachurus japonicus in the shelf-break region of the southern East China Sea. Cont Shelf Res 28: $2574-2583$

Editorial responsibility: Stylianos Somarakis, Heraklion, Greece
Schoener TW (1970) Non-synchronous spatial overlap of lizards in patchy habitats. Ecology 51:408-418

Scoles DR, Collette BB, Graves JE (1998) Global phylogeography of mackerels of the genus Scomber. Fish Bull 96:823-842

Sezaki K, Kuboshima Y, Mitani I, Fukui A, Watabe S (2001) Identification of chub and spotted mackerels with mitochondorial cytochrome $b$ gene and its application to respective pelagic eggs fixed with formalin. Bull Jpn Soc Sci Fish 67:17-22 (in Japanese with English abstract)

Takahashi M, Watanabe Y (2004) Growth rate-dependent recruitment of Japanese anchovy Engraulis japonicus in the Kuroshio-Oyashio transitional waters. Mar Ecol Prog Ser 266:227-238

- Takasuka A, Aoki I (2006) Environmental determinants of growth rates for larval Japanese anchovy Engraulis japonicus in different waters. Fish Oceanogr 15:139-149

Takasuka A, Aoki I, Mitani I (2003) Evidence of growth-selective predation on larval Japanese anchovy Engraulis japonicus in Sagami Bay. Mar Ecol Prog Ser 252:223-238

- Takasuka A, Oozeki Y, Kubota H (2008) Multi-species regime shifts reflected in spawning temperature optima of small pelagic fish in the western North Pacific. Mar Ecol Prog Ser 360:211-217

Tang TY, Tai JH, Yang YJ (2000) The flow pattern north of Taiwan and the migration of the Kuroshio. Cont Shelf Res 20:349-371

Watanabe T (1970) Morphology and ecology of early stages of life in Japanese common mackerel, Scomber japonicus Houttuyn, with special reference to fluctuation of population. Bull Tokai Reg Fish Res Lab 62:1-283 (in Japanese with English abstract)

Wilks DS (1995) Statistical methods in the atmospheric sciences: an introduction. Academic Press, New York

Wong GTF, Chao SY, Li YH, Shiah FK (2000) The Kuroshio edge exchange processes (KEEP) study - an introduction to hypotheses and highlights. Cont Shelf Res 20:335-347

Xu ZL, Zhang D (2010) Yield-density model for determining optimal temperature and salinity for zooplankton: case studies with Appendicularia in the East China Sea. Bull Mar Sci 86:149-164

Yamashita Y, Bailey KM (1989) A laboratory study of the bioenergetics of larval walleye pollock, Theragra chalcogramma. Fish Bull 87:525-536

Yamashita Y, Tanaka M, Miller JM (2001) Ecophysiology of juvenile flatfish in nursery grounds. J Sea Res 45: 205-218

Yukami R, Oshimo S, Yoda M, Hiyama Y (2009) Estimation of the spawning grounds of chub mackerel (Scomber japonicus) and spotted mackerel ( $S$. australasicus) in the East China Sea based of catch statistics and biometric data. Fish Sci 75:167-174

Submitted: May 18, 2010; Accepted: September 16, 2010 Proofs received from author(s): November 22, 2010 